\title{
PREVALENCE OF METABOLIC SYNDROME AMONG POSTMENOPAUSAL WOMEN IN MONTENEGRO - RELATION TO HYPERURICEMIA
}

\section{PREVALENCA METABOLIČKOG SINDROMA KOD ŽENA U POSTMENOPAUZI U CRNOJ GORI - POVEZANOST SA HIPERURIKEMIJOM}

\author{
Milovan Jovanović (1), Aleksandra Klisić (1), Nebojša Kavarić (1), Verica Škerović (2)
}

(1) PRIMARY HEALTH CARE CENTRE, PODGORICA, MONTENEGRO, (2) CLINICAL CENTRE, PODGORICA, MONTENEGRO

\begin{abstract}
Summary: Aim: The data regarding the prevalence of metabolic syndrome (MetS) among postmenopausal women in Montenegro is limited. Therefore, the aim of this study was to evaluate this prevalence and to examine its association with serum uric acid level, an established cardiometabolic risk factor. Methods: A total of 242 postmenopausal women (aging 43-68) were included. Fasting glucose, lipid parameters, and uric acid were determined with the standard procedure. Blood pressure and anthropometric parameters were obtained. MetS was diagnosed according to the modified US National Cholesterol Education Program Adult Treatment Panel III guidelines. Results: The prevalence of MetS in postmenopausal women was $42.1 \%$. The most prevalent component was abdominal obesity $(65.3 \%)$, following by hypertension (systolic blood pressure and diastolic blood pressure accounting for $54.1 \%$ and $49.2 \%$ respectively), hyperglycemia (40.5\%), and dyslipidemia (high triglycerides and low HDL-c level accounting for $30.2 \%$ and $25.2 \%$ respectively). Uric acid levels were significantly higher in postmenopausal women with MetS than in those without MetS $(\mathrm{P}<0.001)$. Moreover, a significantly higher number of patients with MetS as compared to subjects without diagnosed MetS across uric acid tertiles was found $(\chi 2=27.02, \mathrm{P}<0.001)$. Conclusion: MetS is highly prevalent among postmenopausal women in Montenegro and correlated with higher uric acid level. Abdominal obesity is the most prevalent feature of the syndrome. This suggests the importance of reducing obesity and lowering uric acid level in prevention of cardiometabolic diseases.
\end{abstract}

Keywords: abdominal obesity, metabolic syndrome, postmenopausal, uric acid

Sažetak: $\quad$ Cilj: Nema podataka o prevalenci metaboličkog sindroma (MetS) kod žena u periodu postmenopauze u Crnoj Gori. Stoga je cilj studije bio da se utvrdi ova prevalenca i ispita povezanost MetSa sa mokraćnom kiselinom u serumu, poznatim kardiometaboličkim faktorom rizika. Metode: U studiju su uključene 242 žene u postmenopauzi (starosti 43-68 godina). Glikemija našte, lipidni status i mokraćna kiselina su određivani standardnom procedurom. Mereni su i krvni pritisak i antropometrijski parametri. MetS je dijagnostikovan prema modifikovanim smernicama Američkog nacionalnog programa za edukaciju o holesterolu - Preporuke panela III za lečenje odraslih. Rezultati: Prevalenca MetS-a kod žena u postmenopauzi je iznosila $42,1 \%$. Najučestalija komponenta je bila abdominalna gojaznost $(65,3 \%)$, potom hipertenzija (sistolna - 54,1\% i dijastolna - 49,2\%), hiperglikemija (40,5\%), dislipidemija (hipertrigliceridemija - 30,2\%) i niske vrednosti lipoproteina velike gustine (HDL-holesterol - 25,2\%). Srednje vrednosti serumske mokraćne kiseline bile su značajno više kod žena sa MetS-om u poređenju sa kontrolnom grupom $(P<0,001)$. Takođe, značajno veći broj ispitanica sa MetS-om je zabeležen u tercilnoj grupi sa najvišom koncentracijom mokraćne kiseline u serumu $\left(\chi^{2}=27,02 ; P<0,001\right)$. Zaključak: Zabeležena je visoka prevalenca MetS-a kod žena u postmenopauzi u Crnoj Gori, kao i povezanost sa višom koncentracijom mokraćne kiseline u serumu. Centralna gojaznost je najučestalija karakteristika sindroma. Ovo ukazuje na značaj smanjenja gojaznosti i mokraćne kiseline u ovom periodu u cilju prevencije i smanjenja kardiometaboličkih poremećaja.

Ključne reči: abdominalna gojaznost, metabolički sindrom, postmenopauza, mokraćna kiselina

Adresa autora: Aleksandra Klisić, Primary Health Care Center, Trg Nikole Kovačevića 6, 81000 Podgorica, Montenegro. E-mail: aleksandraklisic@gmail.com

Rad primljen: 31. 5. 2016. Rad prihvaćen: 30. 7. 2016. Elektronska verzija objavljena: 7. 11. 2016. 


\section{INTRODUCTION}

A key feature of the menopausal transition is the reduction in estradiol levels [1]. Consequently, many of the components of metabolic syndrome (MetS) (central obesity, dyslipidemia, impaired fasting glucose and hypertension) are often seen in that period [2], and numerous studies have shown that being affected by MetS increases the risk, as well as morbidity of cardiovascular disease (CVD) $[3,4]$. The prevalence of the MetS is increasing rapidly throughout the world. Studies about MetS have shown that females were more affected than males [5]. Moreover, the prevalence of MetS increases in women after menopause [6].

Although the MetS is multifactorial in origin, impaired glucose tolerance, dyslipidemia, and hypertension are caused by the same underlying mechanism-endothelial dysfunction primarily mediated by oxidative stress. A growing body of evidence suggests that increased oxidative stress to adipocytes is central in the pathogenesis of CVD in MetS [7].

On the other hand, uric acid is regarded as independent risk factor for CVD [8]. In addition, elevated uric acid impairs endothelial function by inducing intracellular oxidative stress and inflammation through activation of the local renin-angiotensin system, and the prooxidant effect of uric acid per se, once absorbed into endothelial cells [9].

In line with this, it is speculated that uric acid is one of the determinants of the MetS [10]. The elevated serum uric acid level observed in the MetS has been attributed to hyperinsulinemia, since insulin reduces renal excretion of uric acid [11].

Data concerning the prevalence of MetS among postmenopausal women in Montenegro are limited. Therefore, the aim of this study was to evaluate the prevalence of this syndrome and to examine its association with serum uric acid, an established cardiometabolic risk factor.

Materials and methods

\section{STUDY POPULATION}

The study enrolled a total of 242 women (ages 43-68 years) who developed menopause and who volunteered to participate in the study. Participants were consecutively recruited in the study when seeking gynaecologic healthcare in the Primary Health Care Centre in Podgorica, in a period from October 2012 to May 2013. All the participants completed a questionnaire including demographic characteristics, somatic illnesses, medications use, and lifestyle habits. Menopause is defined as having last menstrual cycle for more than one year. Inclusion criteria were: women without signs and symptoms of acute inflammatory disease, with no history or the presence of malignancy, hypo- and hyperthyroidism, or CVD. Participants who had gout, renal dysfunction, hepatic dysfunction, cardiovascular disorders were excluded from the study, as well as those who used antiinflammatory medications or hormonal replacement therapy. The participants were instructed not to perform any vigorous physical activity the day before the blood samples were taken. Medical history and clinical examinations were carried out on the same day. All the participants provided written informed consent. The study protocol was approved by Ethical Committee of Primary Health Care Centre in Podgorica and the research was carried out in compliance with the Declaration of Helsinki [12].

\section{Anthropometric measurements}

Basic anthropometric measurements: body height $(\mathrm{cm})$, body weight $(\mathrm{kg})$ and waist circumference (WC) $(\mathrm{cm})$ were obtained twice in the morning on the same day and the mean values were used for the analysis. Body mass index (BMI) was calculated as weight in kilograms divided by height in meters squared $(\mathrm{kg} / \mathrm{m} 2)$. All measurements were taken by the same trained evaluator. Blood pressure was measured with a sphygmomanometer after the subject had been seated for 15 minutes. The average of three measurements taken on the right arm was recorded.

The participants were divided into two groups: group of postmenopausal women without MetS $(\mathrm{n}=140)$, and group of postmenopausal women with MetS ( $\mathrm{n}=102)$. MetS was diagnosed according to the modified US National Cholesterol Education Program Adult Treatment Panel III (NCEP ATP III) guidelines [13]. The participants met with at least three or more of the following conditions were diagnosed with MetS:

1. Waist circumference $(\mathrm{WC}) \geq 88 \mathrm{~cm}$;

2. Hyperglicemia $\geq 5.6 \mathrm{mmol} / \mathrm{L}$ or antidiabetic medication use (instead of previous cut-off values of fasting plasma glucose $\geq 6.1 \mathrm{mmol} / \mathrm{L}$ ); 3. High density lipoprotein cholesterol (HDL-c) $\leq 1.29 \mathrm{mmol} / \mathrm{L}$; 
4. Triglycerides $\geq 1.70 \mathrm{mmol} / \mathrm{L}$ or lipid lowering medication use;

5. Hypertension: systolic blood pressure (SBP) or diastolic blood pressure (DBP) $\geq 130 / 85 \mathrm{~mm}$ $\mathrm{Hg}$ and/or diagnosed hypertension treated with antihypertensive therapy.

\section{Biochemical analyses}

Blood samples were taken between 7-9 hours a.m., after 12-14 hours of an overnight fast. Samples were left to clot for 30 minutes and then centrifuged at $3000 \mathrm{rpm}$ for 10 minutes. Serum levels of glucose, total cholesterol (TC), high density lipoprotein cholesterol (HDL-c), low density lipoprotein cholesterol (LDL-c), triglycerides (TG) and uric acid level were measured using standardized enzymatic procedures using a spectrophotometer (Roche Cobas 400, Mannheim, Germany).

\section{Statistical analysis}

Statistical analyses were performed using SPSS statistical package (version 15.0 for Windows, SPSS, Chicago, IL, USA). Data are presented as mean \pm standard deviation or median (interquartile range), or counts and percentages. Differences in uric acid level between groups were evaluated with a Student's $t$ test, and $\chi^{2}$-test was used for categorical variables. Receiver Operating Characteristic (ROC) curve analysis was used with the purpose of testing discriminatory capability of uric acid with MetS status as dependent variable. In all analyses, $\mathrm{P}$ value of $<0.05$ was considered as statistically significant.

\section{RESULTS}

Table 1 shows the general clinical and biochemical characteristics of the study participants.

Data are presented as mean \pm standard deviation or median (interquartile range), or counts and percentages; BMI-Body mass index; WC-Waist circumference; HDL-c-High density lipoprotein cholesterol; LDL-c-Low density lipoprotein cholesterol; TG-Triglycerides; SBPSystolic blood pressure; DBP-Diastolic blood pressure

The prevalence of MetS and its components is presented in Table 2. MetS is diagnosed in $42.1 \%$ of women. As shown, the most prevalent feature was abdominal obesity $(65.3 \%)$, following by hypertension (systolic blood pressure (SBP) and diastolic blood pressure (DBP) accounting for $54.1 \%$ and $49.2 \%$ respectively), hyperglycemia (40.5\%), and dyslipidemia (high triglycerides and low HDL-c level accounting for $30.2 \%$, and $25.2 \%$ respectively).

Table 1. General characteristics of studied postmenopausal women

Tabela 1. Opšte karakteristike ispitivanih žena u postmenopauzi.

\begin{tabular}{|c|c|}
\hline Characteristics & $\begin{array}{c}\text { Postmenopausal } \\
\text { women (n=242) }\end{array}$ \\
\hline Age (years) & $56.7 \pm 4.52$ \\
\hline BMI $\left(\mathrm{kg} / \mathrm{m}^{2}\right)$ & $27.2 \pm 4.00$ \\
\hline WC $(\mathrm{cm})$ & $92.7 \pm 12.43$ \\
\hline Fasting glucose $(\mathrm{mmol} / \mathrm{L})$ & $5.40(5.10-6.00)$ \\
\hline Total cholesterol $(\mathrm{mmol} / \mathrm{L})$ & $6.24 \pm 1.12$ \\
\hline HDL-c $(\mathrm{mmol} / \mathrm{L})$ & $1.56(1.29-1.83)$ \\
\hline LDL-c $(\mathrm{mmol} / \mathrm{L})$ & $3.89(3.25-4.58)$ \\
\hline TG $(\mathrm{mmol} / \mathrm{L})$ & $1.37(0.99-1.76)$ \\
\hline Uric acid $(\mu \mathrm{mol} / \mathrm{L})$ & $276 \pm 62.0$ \\
\hline SBP $(\mathrm{mm} \mathrm{Hg})$ & $133 \pm 21.3$ \\
\hline DBP $(\mathrm{mm} \mathrm{Hg})$ & $83.7 \pm 12.3$ \\
\hline Current smokers $\%(\mathrm{n})$ & $16.9(41)$ \\
\hline $\begin{array}{c}\text { Antihypertensive drugs } \% \\
(\mathrm{n})\end{array}$ & $36.0(87)$ \\
\hline Lipid lowering drugs \% (n) & $13.2(32)$ \\
\hline Hypoglycemic drugs $\%(\mathrm{n})$ & $19.4(47)$ \\
\hline
\end{tabular}

Table 2. The prevalence of metabolic syndrome and its components among postmenopausal women

Tabela 2. Prevalenca metaboličkog sindroma i njegovih komponenti kod žena u postmenopauzi.

\begin{tabular}{|c|c|}
\hline $\begin{array}{c}\text { The prevalence of MetS and its } \\
\text { components among } \\
\text { postmenopausal women }\end{array}$ & $\%$ \\
\hline MetS & 42.1 \\
\hline $\mathrm{WC} \geq 88 \mathrm{~cm}$ & 65.3 \\
\hline Fasting glucose $\geq 5.6 \mathrm{mmol} / \mathrm{L}$ & 40.5 \\
\hline $\mathrm{HDL}-\mathrm{c} \leq 1.29 \mathrm{mmol} / \mathrm{L}$ & 25.2 \\
\hline $\mathrm{TG} \geq 1.70 \mathrm{mmol} / \mathrm{L}$ & 30.2 \\
\hline $\mathrm{SBP} \geq 130 \mathrm{~mm} \mathrm{Hg}$ & 54.1 \\
\hline $\mathrm{DBP} \geq 85 \mathrm{~mm} \mathrm{Hg}$ & 49.2 \\
\hline
\end{tabular}
circumference; HDL-c-High density lipoprotein cholesterol; TG-Triglycerides; SBP-Systolic blood pressure; DBP-Diastolic blood pressure

In the current study we also aimed to test the association of MetS status with uric acid level. We found significantly higher number of 
patients with MetS compared to subjects without diagnosed MetS across uric acid tertiles $(\chi 2=27.02, \mathrm{P}<0.001)$ ), (Table 3$)$. This confirmed, at least partially, the association of uric acid with MetS status in postmenopausal women in our study.
In addition, we found significantly higher uric acid levels were in postmenopausal women with MetS than in those without MetS (304 \pm 61.1 vs. $256 \pm 54.7 \mu \mathrm{mol} / \mathrm{L}, \quad \mathrm{P}<0.001)$, (Graph 1).

Table 3. Metabolic syndrome distribution in uric acid tertiles values subgroups

Tabela 3. Distribucija metaboličkog sindroma prema tercilnim vrednostima mokraćne kiseline.

\begin{tabular}{|c|c|c|c|c|}
\hline \multirow[b]{2}{*}{ MetS status } & \multicolumn{3}{|c|}{ Uric acid tertiles values } & \multirow[b]{2}{*}{$\mathrm{P}^{*}$} \\
\hline & $\begin{array}{l}\text { I tertile }(\mathrm{n}=99) \\
\leq 251 \mu \mathrm{mol} / \mathrm{L}\end{array}$ & $\begin{array}{l}\text { II tertile }(\mathrm{n}=106) \\
252-350 \mu \mathrm{mol} / \mathrm{L}\end{array}$ & $\begin{array}{l}\text { III tertile }(\mathrm{n}=37) \\
\geq 350 \mu \mathrm{mol} / \mathrm{L}\end{array}$ & \\
\hline MetS +, n (\%) & $24(23.5 \%)$ & $52(51.0 \%)$ & $26(25.5 \%)$ & $\chi 2=27.02$ \\
\hline MetS -, n (\%) & $75(53.6 \%)$ & $54(38.6 \%)$ & $11(7.9 \%)$ & $\mathrm{P}<0.001$ \\
\hline
\end{tabular}

MetS+ women with Metabolic syndrome; MetS- women without Metabolic syndrome

Graph 1. Serum uric acid levels in postmenopausal women according to metabolic syndrome status Dijagram 1. Serumske vrednosti mokraćne kiseline u odnosu na prisustvo metaboličkog sindroma.

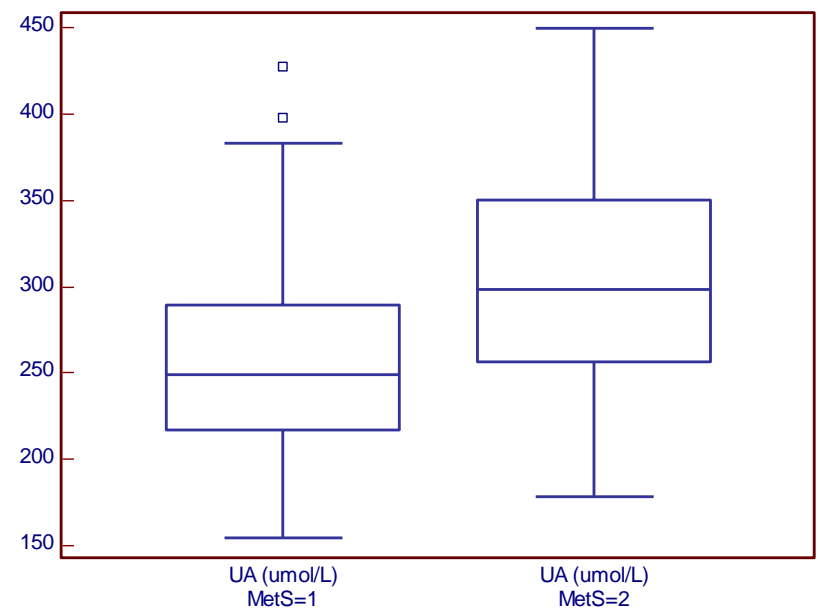

UA-uric acid; MetS=1-women without metabolic syndrome; MetS=2-women with metabolic syndrome

Thereafter, we conducted a receiver operating characteristic (ROC) analysis to test the discriminatory capability of uric acid regarding MetS status. Figure 1 shows ROC curve graph and Table 4 shows the most important ROC parameters: area under the curve (AUC) with 95\% confidence interval (CI) of selected parameter.

ROC curve showed good discriminatory capability (AUC=0.722, according to Hosmer and Lemeshow's rules) toward the MetS status [14].

Table 4. Area under the curve, 95\% Confidence Interval and Standard error for the uric acid discriminatory capability regarding the metabolic syndrome status

Tabela 4. Površina ispod krive, 95\% Interval poverenja i standardna greška diskriminacione moći mokraćne kiseline u odnosu na metabolički sindrom.

\begin{tabular}{|c|c|c|c|c|c|c|}
\hline Parameter & AUC & $95 \%$ CI & SE & $\begin{array}{c}\text { Sensitivity } \\
(\%)\end{array}$ & $\begin{array}{c}\text { Specificity } \\
(\%)\end{array}$ & P \\
\hline Uric acid & 0.722 & $0.661-0.777$ & 0.034 & 64.7 & 71.4 & $<0.001$ \\
\hline
\end{tabular}

AUC - area under ROC curve; CI- Confidence interval; SE-standard error 
Figure 1. ROC curve of the uric acid discriminatory capability regarding the metabolic syndrome status Slika 1. ROC kriva diskriminacione moći mokraćne kiseline u odnosu na metabolički sindrom.

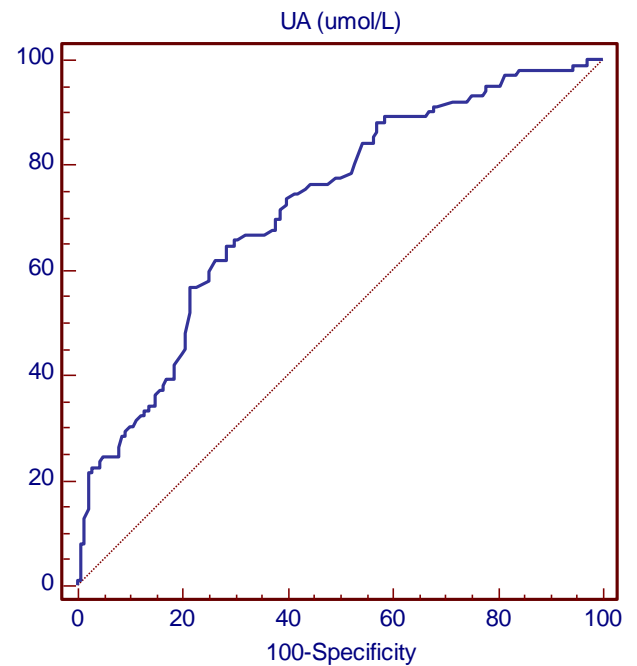

\section{DISCUSSION}

The incidence of MetS among postmenopausal women was found to be drastically increased in the world. In the current study the prevalence of MetS was $42.1 \%$, with abdominal obesity as the most prevalent feature $(65.3 \%)$ which is similar with the results of the other studies [15]. The high prevalence of MetS among postmenopausal women in the world varies from $32.6 \%$ in Austria, to $54.6 \%$ in South Korea [16]. In Chinese postmenopausal women the prevalence of MetS was 33.7\% [17]. According to a study of Pandey et al. [18] the prevalence of MetS among Indian postmenopausal women was 55\%. Moreover, MetS was highly prevalent among Brasilian postmenopausal women [19], and the most prevalent risk factor was abdominal obesity, affecting $62.5 \%$ of women. MetS also seems to be a major health problem among postmenopausal women in many developing countries, like Bangladesh, accounting for $39.3 \%$ of postmenopausal women having MetS. Even more, the prevalence of MetS was 1.78 times higher in postmenopausal women than in premenopausal ones [19]. Neto et al. [6] found that women between 40 and 45 years had a prevalence of MetS of $14.1 \%$, while for women between 56 and 64 years the prevalence was even $66.7 \%$.

The obtained results of the current study are unexpected. Taking into account that Montenegro is the part of Mediterranean basin, and that Mediterranean-type dietary pattern would be expected as the preferable one due to easy access of consumers to the Mediterranean products, these results are discouraging. The possible explanation for this may be the sedentary lifestyle and unhealthy dietary pattern, with the increasing prevalence of obesity.

It is important to note that this prevalence would be expected to be even higher if we take into consideration the International Diabetes Federation criteria (IDF), with lower WC cut-off values $\leq 80 \mathrm{~cm}$ [20] than reported in the current study.

In addition to the assessment of traditional risk factors, as components of MetS, we have been explored serum uric acid level and showed its good discriminatory capability toward MetS status. In line with previous studies [21-23] we reported higher serum uric acid level in women with MetS, comparing to those without MetS. Moreover, in a prospective study conducted by Zurlo et al. [24] high serum uric acid levels significantly and independently predicted MetS in older women, but not in men, over a 4.4-year follow-up.

The underlying mechanism of the association between serum uric acid levels and MetS risk remains poorly elucidated. The elevated serum uric acid level observed in the MetS has been attributed to hyperinsulinemia, since insulin reduces renal excretion of uric acid [11]. In animal studies, hyperuricemia might induce MetS by two mechanisms. Firstly, hyperuricemia may have a causal role in the pathogenesis of insulin resistance. High levels of serum uric acid inhibit endothelial nitric oxide 
(NO) bioavailability and insulin requires endothelial NO to stimulate skeletal muscle glucose uptake. Secondly, hyperuricemia induces oxidative and inflammatory changes in adipocytes, inducing MetS in obese mice [25]. In addition to this, we previously reported a significant relationship between serum uric acid level and anthropometric parameters, stronger with WC than with BMI, implicating that visceral adipose tissue is the main determinant of serum uric acid level [26]. Furthermore, in our previous study we showed that uric acid correlated with the majority of components of MetS, including insulin resistance. However, these correlations were not retained in multiple regression analysis, while only abdominal obesity (as measured by WC), which is the most prevalent feature of MetS in the current study, remained significant independent predictor of higher uric acid levels. Central obesity progressively increases hepatic and adipose tissue insulin resistance with consequent metabolic abnormalities like impaired glucose tolerance, decreased HDL-c, elevated triglycerides and hypertension [27]. These results suggest an important mechanism through which obesity and hyperuricemia can influence on higher risk of MetS and CVD.

Several limitations of our study must be emphasized. The subjected patients were not asked to discontinue their medications, such as antihypertensive, lipid-lowering and hypoglycemic drugs. Furthermore, since this was a cross-sectional study, the causal relationship between MetS and uric acid level in postmenopausal women could not be established. Above of this, as our study was not based on general population, selection bias might have affected the outcome of the study. Thus larger sample size in general population may be required to confirm the results of the present study.

\section{CONCLUSION}

To our knowledge the current study is the first one to examine the prevalence of metabolic syndrome among postmenopausal women in Montenegro. The obtained results are discouraging, but do not significantly differ from other countries, which is in accordance with the results of the increasing prevalence of MetS among postmenopausal women in the world. It is clear that weight gain and central obesity drives the increased prevalence of MetS in postmenopausal women. The most prevalent feature in our study was abdominal obesity which supported these findings. Furthermore, women with MetS displayed higher serum uric acid levels, as compared with those without MetS. This suggests the importance of reducing obesity and lowering uric acid level in prevention of cardiometabolic diseases.

\section{Conflict of Interest Statement}

The authors have declared no conflicts of interest.

\section{REFERENCES}

1. Janssen I, Powell LH, Crawford S, Lasley B, Sutton-Tyrrell K. Menopause and the Metabolic Syndrome: The Study of Women's Health Across the Nation. Arch Intern Med 2008; 168 (14): 1568-1575.

2. Carr MC. The emergence of the metabolic syndrome with menopause. J Clin Endocrinol Metab 2003; 88: 2404 2411.

3. Wilson PW, D'Agostino RB, Parise H, Sullivan L, Meigs JB. Metabolic syndrome as a precursor of cardiovascular disease and type 2 diabetes mellitus. Circulation 2005; 112: 3066-3072.

4. Liu J, Grundy SM, Wang W, Smith SC Jr, Vega GL, Wu Z, et al. Ten year risk of cardiovascular incidence related to diabetes, prediabetes and the metabolic syndrome. Am Heart J 2007; 153: 552-558.

5. Marjani A. A review on metabolic syndrome. J Endocrinol Metab 2012; 2(4-5): 166-170.

6. Neto JAF, Figueredo ED, Barbosa JB, Fde FB, Costa GR, Nina VJ, et al. Metabolic syndrome and menopause: Cross-Sectional Study in Gynecology Clinic. Bras Arch Cardiol 2010; 95(3): 339-345.

7. Maury E, Brichard SM. Adipokine dysregulation, adipose tissue inflammation and metabolic syndrome. Mol Cell Endocrinol 2010; 314: 1-16.

8. Ioachimescu AG, Brennan DM, Hoar BM, Hazen SL, Hoogwerf BJ. Serum uric acid is an independent predictor of all-cause mortality in patients at high risk of cardiovascular disease: a preventive cardiology information system (PreCIS) database cohort study. Arthrit Rheum 2008; 58(2): 623-630.

9. Yu MA, Sanchez-Lozada LG, Johnson RJ, Kang DH. Oxidative stress with an activation of the reninangiotensin system in human vascular endothelial cells as a novel mechanism of uric acid-induced endothelial dysfunction. J Hypertens 2010; 28(6): 1234-1242.

10. Nejatinamini S, Ataie-Jafari A, Qorbani M, Nikoohemat $S$, Kelishadi R, Asayesh $\mathrm{H}$, et al. Association between serum uric acid level and metabolic syndrome components. J Diabetes Metab Disord 2015; 14: 70

11. Galvan AQ, Natali AN, Baldi SI, Frascerra SI, Sanna GI, Ciociaro DE, et al. Effect of insulin on uric acid excretion in humans. Am J Physiol Endocrinol Metab 1995; 268(1): E1-5.

12. World Medical Association declaration of Helsinki: Recommendations guiding physicians in biomedical research involving human subjects. JAMA 1997; 277: 925-926.

13. Grundy SM, Cleeman JI, Daniels SR, Donato KA, Eckel RH, Franklin BA, et al. Diagnosis and management of the metabolic syndrome: an American Heart 
Association/National Heart, Lung, and Blood Institute Scientific Statement. Circulation 2005; 112: 2735-2752.

14. Hosmer D, Lemeshow S, Sturdivant RX. Applied logistic regression, 3rd ed. New York, NY: John Wiley \& Sons Inc 2013.

15. Petri Nahas EA, Padoani NP, Nahas-Neto J, Orsatti FL, Tardivo AP, Dias R. Metabolic syndrome and its associated risk factors in Brazilian postmenopausal women. Climacteric 2009; 12(5): 431-438.

16. Jouyandeh Z, Nayebzadeh F, Qorbani M, Asadi M. Metabolic syndrome and menopause. J Diabet Metab Dis 2013; $12: 1$.

17. Ruan X, Jin J, Hua L, Liu Y, Wang J, Liu S. The prevalence of metabolic syndrome in Chinese postmenopausal women and the optimum body composition indices to predict it. Menopause 2010; 17(3): 566-570.

18. Pandey S, Srinivas M, Agashe S, Joshi J, Galvankar P, Prakasam $\mathrm{CP}$, et al. Menopause and metabolic syndrome: A study of 498 urban women from western India. J Midlife Health 2010; 1: 63-69.

19. Jesmin S, Islam AMS, Akter S, Islam MM, Sultana SN, Yamaguchi N, et al. Metabolic syndrome among pre- and post-menopausal rural women in Bangladesh: result from a population-based study. BMC ResNotes 2013; 6(1): 157.

20. International Diabetes Federation- IDF. The IDF consensus worldwide definition of the metabolic syndrome. Brussels: IDF, 2005.
21. Li Y, Chen S, Shao X, Guo J, Liu X, Liu A, et al. Association of uric acid with metabolic syndrome in men, premenopausal women and postmenopausal women. Int J Environ Res Public Health 2014; 11(3): 2899-2910.

22. Liu PJ, Ma F, Lou HP, Zhu YN, Chen Y. Relationship between serum uric acid levels and metabolic syndrome in Chinese postmenopausal women. Climacteric 2014; 17(2): 148-154.

23. Dai X, Yuan J, Yao P, Yang B, Gui L, Zhang X, et al. Association between serum uric acid and the metabolic syndrome among a middle- and old-age Chinese population. Eur J Epidemiol 2013; 28: 669-676.

24. Zurlo A, Veronese N, Giantin V, Maselli M, Zambon S, Maggi S, et al. High serum uric acid levels increase the risk of metabolic syndrome in elderly women: The PRO.V.A study. Nutr Metab Cardiovas 2016; 26(1): 27 35.

25. Sautin YY, Nakagawa T, Zharikov S, Johnson RJ. Adverse effects of the classical antioxidant uric acid in adipocytes: NADPH oxidase-mediated oxidative/nitrosative stress. Am J Physiol Cell Physiol 2007; 293: C584-C596.

26. Klisić A, Kotur-Stevuljević J, Kavarić N, Jovanović M. The influence of obesity on serum uric acid level in postmenopausal women. Timočki medicinski glasnik 2016; 41(1): 20-26.

27. Wang Z, and Nakayama T. Inflammation, a Link between Obesity and Cardiovascular Disease. Mediators Inflamm 2010; 2010: 535918. 